\title{
Enhancing biogas production by anaerobic co- digestion of water hyacinth and pig manure
}

\author{
Gia tăng lương khí sinh học tù đồng phân hủy yếm khí lục bình và phân heo \\ Research paper
}

Tran Sy $\mathrm{Nam}^{1 *}$; Le Ngoc Dieu Hong ${ }^{2}$; Huynh Van Thao ${ }^{1}$; Nguyen Huu Chiem ${ }^{1}$; Le Hoang Viet $^{1}$; Kjeld Ingvorsen ${ }^{3}$; Nguyen Vo Chau Ngan ${ }^{1}$

${ }^{I}$ College of Environment and Natural Resources, Cantho University, Vietnam; ${ }^{2}$ College of Engineering Technology and Environment, Cantho College, Vietnam, ${ }^{3}$ Department of Bioscience, Aarhus University, Denmark

\begin{abstract}
The characteristics of anaerobic batch co-digestion of water hyacinth (WH) with pig manure (PM) under seven mixing ratio $100 \% \mathrm{WH} ; 80 \% \mathrm{WH}: 20 \% \mathrm{PM} ; 60 \% \mathrm{WH}: 40 \% \mathrm{PM} ; 50 \% \mathrm{WH}: 50 \% \mathrm{PM}$; $40 \% \mathrm{WH}: 60 \% \mathrm{PM} ; 20 \% \mathrm{WH}: 80 \% \mathrm{PM}$ and $100 \% \mathrm{PM}$ were investigated, each treatment was conducted in five replications with daily loading rate at $1 \mathrm{gVS} . \mathrm{L}^{-1}$.day ${ }^{-1}$. During the anaerobic digestion process of 60 days, maximum biogas production occurred in two periods, the first stage from 12 22 days and second stage from 30 - 35 days. The maximum daily biogas productions from each stage were $17.2 \mathrm{~L} . d a y^{-1}$ and $15.1 \mathrm{~L}^{-d_{a y}}{ }^{-1}$, respectively. The cumulative biogas production varied between $60 \mathrm{~L}(100 \% \mathrm{PM})$ and $360 \mathrm{~L}(60 \% \mathrm{WH}: 40 \% \mathrm{PM})$. The results showed that the biogas yields of co-digestion $40-80 \% \mathrm{WH}$ were higher from 34.6 to $56.1 \%$ in comparison with $100 \% \mathrm{PM}$ and from 109 to $143 \%$ in comparison with $100 \% \mathrm{WH}$. When mixing with $\mathrm{WH}$, treatments were received more methane and the methane contents were higher than $45 \%(\mathrm{v} / \mathrm{v})$ that good for energy using purposes.
\end{abstract}

Nghiên cứu được thực hiện nhằm khảo sát khả năng gia tăng lương khi sinh học khi tiến hành đồng phân hủy yếm khí lục bình (WH) và phân heo (PM) ở các tỉ lẹ phối trộn khác nhau gồm 100\%WH; 80\%WH : 20\% PM; 60\%WH : 40\%PM; 50\%WH : 50\%PM; 40\%WH : 60\%PM; 20\%WH : $80 \% P M$ và 100\%PM. Các nghiệm thức được nạp luợng nguyên liệu là $1 \mathrm{gVS}$ L $^{-1}$.ngày ${ }^{-1}$ và bố trí lặp lại 5 lần. Theo dõi quá trình phân hủy của các nghiệm thức trong 60 ngày ghi nhận có 2 khoảng thời gian luợng khi sản sinh nhiều nhất - giai đoạn 1 tù ngày 12 đến 22, giai đoạn 2 tù̀ ngày 30 đến 35. Luợng khi sản sinh cao nhất tuơng ứng trong mồi giai đoan là 17.2 L.ngày $^{-1}$ và 15.1 L.ngày ${ }^{-1}$. Lương khí tích lũy trong suốt thời gian thi nghiệm ghi nhận thấp nhất ở nghiệm thức $100 \% P M$ đạt $60 \mathrm{~L}$, và cao nhất ở nghiệm thức $60 \%$ WH : 40\%PM đạt 360 L. Năng suất khi sinh ra của các nghiệm thức phối trộn luc bình tù 40 đến $80 \%$ cao hon tù 34,6 đến $56,1 \%$ so với nghiệm thức $100 \%$ PM và cao hon tù $109 \%$ đến $143 \%$ so với nghiệm thức 100\%WH. Hàm luọng mê-tan sinh ra tù các nghiệm thức có phối trộn luc bình ổn định trong khoảng $>45 \%$ đảm bảo nhiệt luợng cho nhu cầu sủ dụng năng luơng.

Keywords: batch anaerobic co-digestion, biogas, mixing ratios, pig manure, water hyacinth

\section{Introduction}

Nowadays, the world strongly depended on fossil energy likes fuels, oil, petrol gas and coal. The burning process of fossil fuels emitted a huge amount of greenhouse gases that caused climate change. Therefore, there are many countries in the world focused on developing of renewable energy sources such as wind power, solar energy and biomass energy. In Vietnam, biogas - a potential renewable energy - was used more and more popular in rural areas because of low-cost and easy application (Chiem \& Matsubara, 2012). The input for biogas production was varied including agricultural wastes, husbandry wastes, and industrial wastes (Bundhoo et al., 2016; Nguyen \& Fricke, 2015; Abbasi et al., 2012). In the Mekong Delta (MD), biogas technology was used for treating husbandry wastes, especially pig manure (PM). However, most of farmers in MD doing their pig pressing in small scale and decentralize. As a result, it is often lacking of input substrates for biogas production when the farmers stop raising pig or start a new pig raising cycle. While, water hyacinth (WH) was abundant 
in MD due to their high density in canal system (Nam et al., 2015). The development of $\mathrm{WH}$ in the river caused many negative effects on environment and water transport. Some researches proved that WH can be used for biogas production (Nguyen \& Fricke, 2015; Ngan et al., 2012; Gunnarsson \& Petersen, 2007; Abdelhamid \& Gabr, 1991). However, high content of lignocellulose and lignin in WH made it hard for decomposition (Harun et al., 2011). Mixing $\mathrm{PM}$ and $\mathrm{WH}$ could balance $\mathrm{C}$ and $\mathrm{N}$ ratio and was beneficial for biological decay (Nam et al., 2015; Ngan et al., 2012). Thus, this study was done in order to find out the suitable mixing ratio between WH and PM for biogas production for application in case of shortage of PM.

\section{Materials and methods}

\subsection{Materials preparation}

WH was collected in the canals in Camtho City, removed the root then sun-dried for 10 days. Before using for anaerobic digestion, it was chopped into the pieces of $10 \pm 0.32$ $\mathrm{cm}(\mathrm{n}=100)$. PM was taken from small pig farm in Tan Phu Thanh village, Chau Thanh district, Hau Giang province. PM was dried in cool place and mixed well before using for experiment.

\subsection{Experimental design}

The experiment was carried out in randomly design in batch digesters with 7 mixing ratios between WH and PM. The batch anaerobic digestion process was done in $21 \mathrm{~L}$ plastic reactors (Nam et al., 2015). Each reactor contented $765 \mathrm{~g}$ VS based on the loading rate of $1 \mathrm{~g} \mathrm{VS}_{\text {added }} \mathrm{L}^{-1}$.day ${ }^{-1}$ (suggested by Appels et al., 2008) in the period of 45 continuous days. WH was pre-treated by biogas effluent in 5 days before loading into the reactors. All gas was collected and stored in an alluvium bag, then its volume and the composition were measured every day.

Table 1. The experiences design

\begin{tabular}{|c|c|c|c|c|}
\hline \multirow{2}{*}{$\begin{array}{c}\text { Mixing ratio } \\
(\% W H: \% P M)\end{array}$} & \multicolumn{2}{|c|}{$V_{S_{\text {loaded }}}(\mathrm{g})$} & \multirow{2}{*}{$\begin{array}{c}\text { Total } \\
\text { VS }_{\text {loade }} \\
\text { d }\end{array}$} & \multirow{2}{*}{$\begin{array}{l}\mathrm{C} / \mathrm{N} \\
\text { ratio }\end{array}$} \\
\hline & $W H$ & $P M$ & & \\
\hline $0: 100$ & - & 765 & 765 & 23.5 \\
\hline $20: 80$ & 153 & 612 & 765 & 25.1 \\
\hline $40: 60$ & 306 & 459 & 765 & 27.0 \\
\hline $50: 50$ & 382.5 & 382.5 & 765 & 28.1 \\
\hline $60: 40$ & 459 & 306 & 765 & 29.3 \\
\hline $80: 20$ & 612 & 153 & 765 & 32.1 \\
\hline $100: 0$ & 765 & - & 765 & 35.6 \\
\hline
\end{tabular}

\subsection{Analytical methods}

The temperature, $\mathrm{pH}$, redox potential of the fermented liquid was measured directly everyday by $\mathrm{pH} / \mathrm{ORP}$ meter
(HM-3IP-DKK TOA, Japan). Biogas volume was determined by drum-type gas volume meter (TG 02, Ritter, Germany). The methane and carbon dioxide content in biogas was determined by gas chromatography (GC 2014 AT Shimadzu, Japan). The VS content of the fermented liquid when starting and ending the experiment also recorded for VS reduction calculation.

\subsection{Data processing}

Data were analyzed by One-way ANOVA and Duncan post-hoc test for multiple comparisons. An alpha $(\alpha)$ level of 0.05 was used to determine the statistical significance of all analysis. Data were checked and transformed as appropriate to meet the normality and variance homogeneity requirements prior to statistical analysis. The analysis was performed by using the statistical software IBM SPSS 20.0 .

\section{Results and discussions}

\subsection{Temperature, pH, redox and alkalinity}

The results showed that temperature of all reactors fluctuated from $29.1-31.1^{\circ} \mathrm{C}$ (Figure 1a), the temperature in all reactors containing mixed PM - WH had the temperature higher than the ones containing pure PM. However, the difference was not high (lower than $0.5^{\circ} \mathrm{C}$ ). The temperature in range of mesophilic temperature and the temperature was suitable for biological decomposition (Ngan et al., 2012).

Figure $1 \mathrm{~b}$ illustrated that $\mathrm{pH}$ of substrates in all reactors ranged from 5.2 - 7.2, the more $\mathrm{WH}$ added the more $\mathrm{pH}$ reduced and the lowest was recorded in $100 \% \mathrm{WH}$ reactors at $\mathrm{pH}$ of 5.46. The result was similar to the findings by $\mathrm{Ye}$ et al. (2013). pH levels of the substrates mixed $\mathrm{WH}$ and PM $(0: 100 ; 20: 80 ; 40: 60 ; 50: 50 ; 60: 40$ and $80: 20)$ were in range of $6.2-8.5$ that suitable for the activity of methanogen batteries (Chandra et al., 2012).

During anaerobic digestion process, redox of all reactors was highly fluctuated from -313 to $-94 \mathrm{mV}$ (Figure 1c); redox value lower than zero indicated the reduction process and it is a good indicator for the anaerobic digestion. When the redox value is smaller than $-200 \mathrm{mV}$, it is easier for converting organic matter to methane. In this study, redox value at most of the time was lower than $-200 \mathrm{mV}$.

Figure 1d showed that the alkalinity of substrate in all reactors ranged from $733-3,307 \mathrm{mg} \mathrm{CaCO}_{3} / \mathrm{L}$, the alkalinity of $100 \% \mathrm{WH}$ substrate was lower than the one of others. The alkalinity ranged from $1,000-3,000 \mathrm{mg} \mathrm{CaCO}_{3} / \mathrm{L}$ was suitable for methanogen batteries' activity (Ren et al., 2004). 

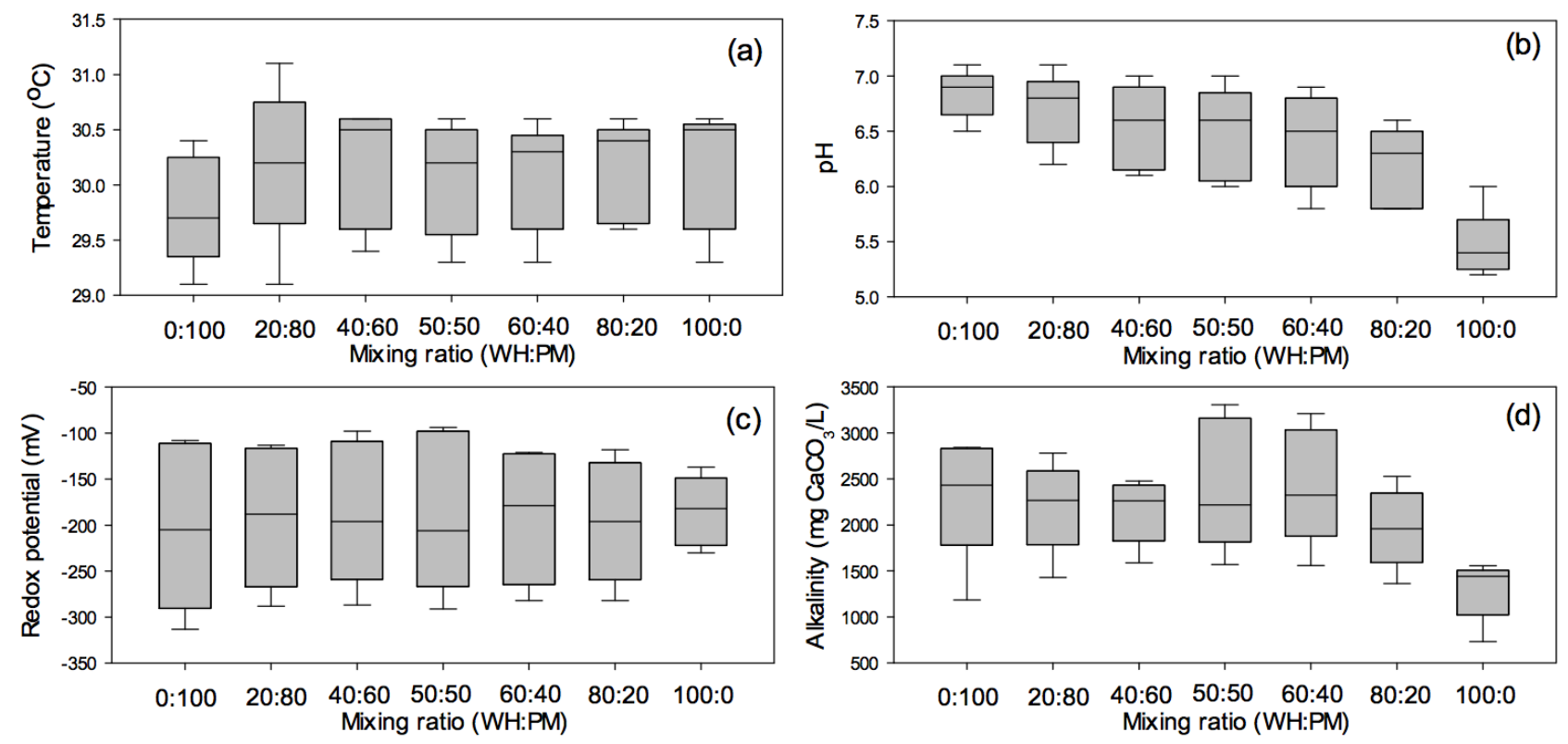

Figure 1. The variation of temperature (a), $\mathrm{pH}(\mathrm{b})$, redox potential (c) and alkalinity (d)

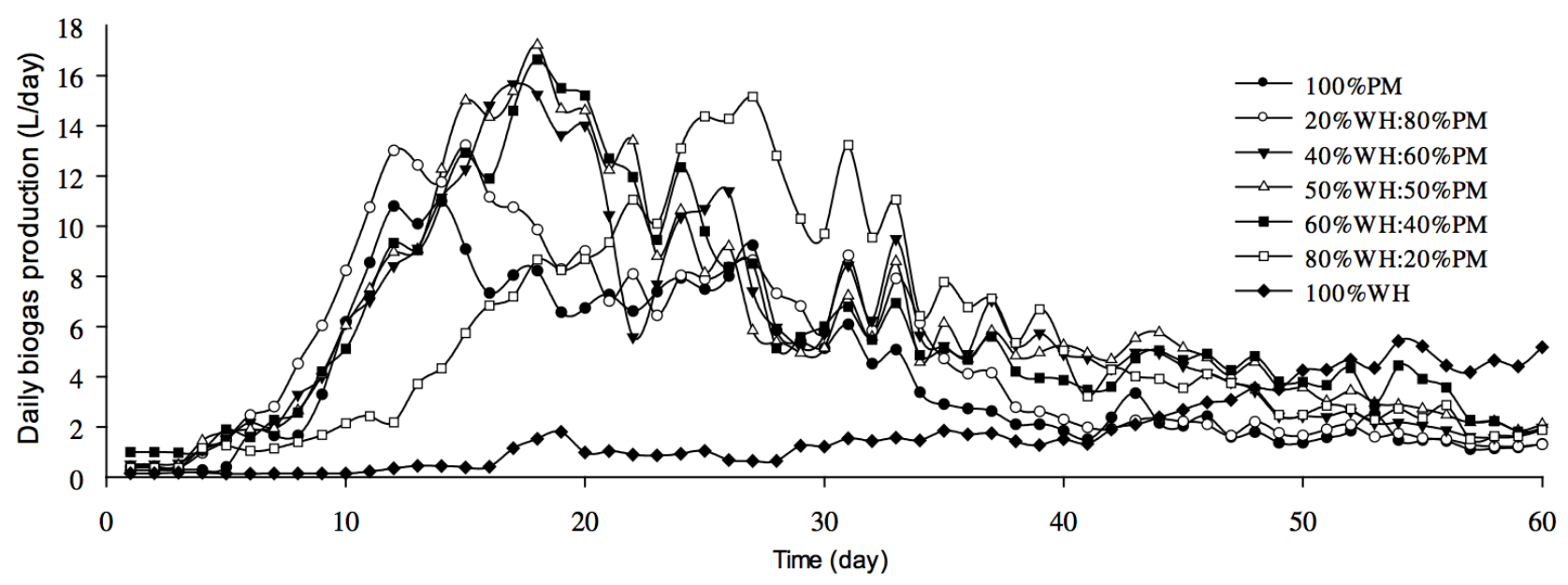

Figure 2. Daily biogas production of WH : PM treatments

\subsection{Daily biogas productions}

Figure 2 showed that there were two periods produced more biogas than others. The first period from the day 12 to 22 with the highest production at $17.2{\mathrm{~L} . \mathrm{day}^{-1}}^{-1}$ in reactor of $50 \% \mathrm{WH}: 50 \% \mathrm{PM}$ and the second period from the day 30 to 35 at $15.1{\mathrm{~L} . \mathrm{day}^{-1}}^{-1}$ in reactor of $80 \% \mathrm{WH}: 20 \% \mathrm{PM}$ (Figure 2). The reactors that mixed PM and WH produced biogas quickly than the pure $\mathrm{PM}$ and pure $\mathrm{WH}$; the $\mathrm{WH}$ reactors produced biogas slower than the PM reactors. While $20 \%, 40 \%, 50 \%, 60 \% \mathrm{WH}$ reactors produced more biogas from the day 12 to 22 , the reactor of $80 \% \mathrm{WH}$ generated more biogas from the day 24 to 34 . After 35 days, daily biogas production was gradually reduced until 60 days. The reactors with more PM reduced daily biogas production stronger than the one with more WH.

\subsection{Cumulative biogas production, biogas yield, methane content and VS reduction}

The results showed that cumulative biogas after 60 days of $40 \% \mathrm{WH}, 50 \% \mathrm{WH}$ and $60 \% \mathrm{WH}$ reactors was highest at $341.8 \mathrm{~L}, 350.5 \mathrm{~L}$ and $358.7 \mathrm{~L}$, respectively. The $80 \% \mathrm{WH}$ reactor had the biogas volume of $330 \mathrm{~L}$ that was lower than the ones of $50 \%$ and of $60 \%$ reactors, but was significant higher than the ones of $20 \% \mathrm{WH}$ reactor (286 L), of $100 \% \mathrm{PM}$ reactor $(190 \mathrm{~L})$ and of $100 \% \mathrm{WH}$ reactor $(102 \mathrm{~L})$ $(p<0.05)$. The statistic analytical results showed that when WH increased from $40 \%$ to $60 \%$ in loading component, biogas production was higher than other mixing ratio treatments $(\mathrm{p}<0.05)$. When the mixing ratio was higher than $60 \% \mathrm{WH}$ or lower than $40 \% \mathrm{WH}$, the cumulative biogas was reduced in comparison with reactors of 40 to $60 \% \mathrm{WH}$. The reactors of $100 \% \mathrm{WH}$ caused $\mathrm{pH}$ dropped to $5.2-5.4$ and inhibited the methanogenic bacteria. Thus biogas productions of these reactors were lower than others. VS reduction of all treatment ranged from $37.8-55.7 \%$ after 60 days; mixing PM and $\mathrm{WH}$ made the decomposition process more quickly than $100 \% \mathrm{WH}$ and $100 \% \mathrm{PM}$. 
Table 2. Cumulative biogas production, biogas yield, VS reduction and methane content

\begin{tabular}{|c|c|c|c|c|}
\hline $\begin{array}{c}\text { Treatments } \\
(\% W H: \% P M)\end{array}$ & $\begin{array}{l}\text { Cumulative biogas } \\
\text { production (L) }\end{array}$ & $\begin{array}{l}\text { VS reduction } \\
(\%)\end{array}$ & $\begin{array}{c}\text { Biogas yield } \\
\left({\mathbf{L} . k g V S^{-1}}_{\text {degraded }}\right)\end{array}$ & $\begin{array}{c}\text { Methane content } \\
(\%)\end{array}$ \\
\hline $0: 100$ & $190^{\mathrm{d}} \pm 24$ & 45.2 & $549^{c} \pm 37$ & $50.45^{\mathrm{ab}} \pm 6.21$ \\
\hline $20: 80$ & $286^{\mathrm{c}} \pm 24$ & 50.7 & $738^{b} \pm 45$ & $52.93^{\mathrm{a}} \pm 4.48$ \\
\hline $40: 60$ & $342^{\mathrm{ab}} \pm 24$ & 55.7 & $803^{\mathrm{ab}} \pm 66$ & $53.05^{\mathrm{a}} \pm 0.96$ \\
\hline $50: 50$ & $351^{a} \pm 24$ & 55.6 & $825^{\mathrm{ab}} \pm 30$ & $52.85^{\mathrm{a}} \pm 1.82$ \\
\hline $60: 40$ & $359^{\mathrm{a}} \pm 24$ & 54.8 & $857^{\mathrm{a}} \pm 59$ & $53.00^{\mathrm{a}} \pm 3.37$ \\
\hline $80: 20$ & $330^{\mathrm{b}} \pm 24$ & 53.1 & $812^{\mathrm{ab}} \pm 50$ & $45.28^{\mathrm{b}} \pm 4.51$ \\
\hline $100: 0$ & $102^{\mathrm{e}} \pm 24$ & 37.8 & $353^{\mathrm{d}} \pm 86$ & $29.55^{c} \pm 6.88$ \\
\hline
\end{tabular}

Note: The number in the same column with the same letter (a, b, c, etc.) was not significant different in ANOVA, Duncan test of $5 \%$

Biogas yields of all treatment ranged from $353-857$ L. $\mathrm{kgVS}^{-1}$ degraded. Biogas yields of $40-80 \% \mathrm{WH}$ reactors were not significant different ( $\mathrm{p}>0.05)$, but different from $100 \% \mathrm{WH}$ and $100 \% \mathrm{PM}$ reactors. Mixing PM and $\mathrm{WH}$ increased biogas yield from 34.6 to $56.1 \%$ and from 109 to $143 \%$ in comparison with $100 \% \mathrm{PM}$ and $100 \% \mathrm{WH}$, respectively. In case of treatment $100 \% \mathrm{WH}, \mathrm{pH}$ drop is the reason inhibiting methanogen then leads to low biogas yield. The results showed that mixing WH with PM can be applied with $40-80 \% \mathrm{WH}$ and all these treatments was not different at biogas production ( $\mathrm{p}>0.05)$.

The methane contents of all treatment ranged from 29.6 $53 \%$. The mixing ratio from 20 to $60 \%$ produced significant higher methane than that of $80 \% \mathrm{PM}$ and of $100 \% \mathrm{PM}$ $(p<0.05)$, but the methane contents from treatments of 0 : 100 and of $80: 20$ were not significant different $(\mathrm{p}>0.05)$. The previous research of Ngan et al. (2012) showed that methane content higher than $45 \%$ can be used for household's cooking. Therefore, methane content of all WH mixed treatments were good for energy using and the biogas can be used for replacing fossil fuel.

\section{Conclusions}

During the anaerobic fermentation process, temperature, $\mathrm{pH}$, redox potential and alkalinity were in optimizing range for biogas production. The daily biogas production separated to two stage: the $1^{\text {st }}$ stage from day of $12^{\text {th }}$ to $22^{\text {nd }}$ and the second stage from day of $30^{\text {th }}$ to $35^{\text {th }}$. Mixing WH to PM from $40 \%$ to $60 \%$ can produced more biogas and increase biogas yield. Mixing treatments of WH and PM can increase biogas production from $34.6 \%$ to $56.1 \%$ and from $109 \%$ to $143 \%$ in comparison to treatment of $100 \% \mathrm{PM}$ and $100 \% \mathrm{WH}$, respectively. Biogas quality from all treatments can be used for cooking.

Acknowledgements: We gratefully acknowledge the support of DANIDA - who funded this research through the SuProM project (DFC File No. 11-016AU) at Can Tho University.

\section{References}

[1] Abbasi T., Tauseef S. M., Abbasi S. A. (2012). Anaerobic digestion for global warming control and en- ergy generation - An overview. Renewable and Sustainable Energy Reviews 16 3228-3242.

[2] Abdelhamid A. M., Gabr A. A. (1991). Evaluation of water hyacinth as feed for ruminants. Archives of Animal Nutrition 41 745-756.

[3] Appels L., Baeyens J., Degrève J., Dewil R. (2008). Principles and Potential of the Anaerobic Digestion of Waste-activated Sludge. Progress in Energy and Combustion Science 34 755-781.

[4] Bundhoo Z. M. A., Sumayya M., Mohee R. (2016). Potential of Biogas Production from Biomass and Waste Materials in the Small Island Developing State of Mauritius. Renewable and Sustainable Energy Reviews 56 1087-1100.

[5] Chandra R., Takeuch H., Hasegawa T. (2012). Methane production from lignocellulosic agricultural crop wastes: A review in context to second generation of biofuel production. Renewable and Sustainable Energy Reviews 16 1462-1476.

[6] Chiem N. H., Matsubara E. (2012). Study on rural development by clean development mechanism. Can Tho University. pp 230 (in Vietnamese).

[7] Gunnarsson C., Petersen C. (2007). Water hyacinths as a resource in agriculture and energy production: A literature review. Waste Manage 27 117-129.

[8] Harun M. Y., Dayang R. A. B., Abidin Z. Z., Yunus R. (2011). Effect of physical pre-treatment on dilute acid hydrolysis of water hyacinth (Eichhornia crassipes). Bioresource Technology 102 5193-5199.

[9] Nam T. S., Chiem N. H., Chi N. P., Viet L. H., Ngan N. V. C., Ingvorsen K. (2015). Effect of biological pretreatment of water hyacinth (Eichhornia crassipes) on biogas production in batch anaerobic digestion with pig manure. Can Tho Unversity Journal of Schience. Special issues on Environment and Climate Change 102-110.

[10] Ngan N. V. C., Thanh N. T, Tan N. T. N., Phuc L. N., Nguon N. T. (2012). Potential use of water hyacinth and rice straw as additional loading materials for biogas digester. Can Tho Unversity Journal of Schience 22a 213-221 (in Vietnamese).

[11] Nguyen V. C. N., Fricke K. (2015). Application of Co-Anaerobic Digester's Effluent for Sustainable 
Agriculture and Aquaculture in the Mekong Delta, Vietnam. Environmental Technology 36 2991-2999.

[12] Ren N. Q., Wang A. J. (2004). The Method and Technology of Anaerobic Digestion. Chemical industry Press, pp. 30-31.
[13] Ye J., Li D., Sun Y., Wang G., Yuan Z., Zhen F., Wang Y. (2013). Improved Biogas Production from Rice Straw by Co-Digestion with Kitchen Waste and Pig Manure. Waste Management 33 2653-58. 